\title{
A Study of the Effects of Bioethanol-Gasoline Blends on Vehicle Emissions
}

\author{
A. Engin Özçelik, Hasan Aydoğan, and Mustafa Acaroğlu
}

\begin{abstract}
The economic value of biofuels has been increasing in the area of energy and in other areas of use due to the increasing energy crisis. The use of ethanol in engines is more common in countries where agricultural crops are abundantly cultivated. Ethanol is a convenient fuel for spark-ignition engines owing to its characteristics and it can be used in engines singly or by blending with gasoline at certain rates. It has been observed that the use of ethanol in motor vehicles results in decreased exhaust emissions of harmful pollutants.

In this study, bioethanol produced from sugar beet was used as a blending component. Gasoline-bioethanol blends containing $2 \%$ and $5 \%$ ethanol by volume were used as fuel in a gasoline engine vehicle and 95 octane gasoline was accepted as the control fuel. As a result of the experiments carried out, it was observed that the use of ethanol resulted in a decrease in $\mathrm{CO}$, $\mathrm{CO}_{2}, \mathrm{HC}$ and NOx emissions and an increase was observed in the value of $\mathrm{O}_{2}$ emissions in the exhaust.
\end{abstract}

Index Terms - Bioethanol, gasoline, vehicle, emission.

\section{INTRODUCTION}

Today, with the beginning of a period in which the fossil based resources that are in use have started to deplete, developed countries have set off on a quest for alternative fuels in order to increase and extend energy diversity trying not to largely depend on certain types of energy sources [1].

Biofuels are the latest and the most widely used type of alternative fuels. The reason why biofuels have quickly become widely used is that they continually gain an increase in economic value and also they do not have a negative effect on the environment [2].

Ethanol can be utilized as a fuel in various areas of usage. As the result of the previous studies conducted on the use of ethanol, it has been stated that ethanol can successfully be used in petrol-operated vehicle engines without a need for any additives and the harmful $\mathrm{HC}$ and $\mathrm{CO}_{2}$ emissions from the engines significantly decrease with the use of ethanol [3].

Bioethanol is a type of clear and colorless alcohol without any poisonous effects which is extracted from the biomass of agricultural crops such as wheat stalk, corn, potatoes and sugar beat. The use of ethanol in engines is widely observed in countries such as Brazil and the United States, where the mentioned types of agricultural products are abundantly cultivated [4].

When we look at the countries where a large amount of

Manuscript received June 26, 2014; revised August 29, 2014.

The authors are with the Department of Mechanical Engineering, Technology Faculty, Selcuk University Campus, Selcuklu, Konya, 42250 Turkey (tel.: +90-332-2233339; fax: +90-332-2412130; e-mail: eozcelik@selcuk.edu.tr, haydogan@selcuk.edu.tr, acaroglu@selcuk.edu.tr). ethanol is produced, we can see that the amount of ethanol needed in these countries has also significantly increased when compared to other countries. Due to their growing demand for ethanol, their production is also increasing day by day. While the amount of ethanol produced in the world was about 36 billion liters two years ago, this amount is expected to increase by $65 \%$ exceeding 60 billion liters in 2010 [5].

The biggest problem in using ethanol in pure form in engines is that as vaporization of ethanol is slow at low temperatures, it becomes difficult to operate the engine under cold weather conditions. This problem can be solved through additives like petrol or by heating the alcohol while entering the engine using electric heaters [6].

Ethanol can easily be used in gasoline engines due to its high octane number. E85 ethanol vehicles which are fueled by a gas mixture made up of 85 percent ethanol and 15 percent gasoline are produced in a limited number as automobile manufacturers have been testing these vehicles. Vehicles that can run on $100 \%$ ethanol or on a blend of gasoline-ethanol up to the limit rate of $85 \%$ are called Flexible Fuel Vehicles. One of the factors that prevent the widespread use of E85 fuel is the need for special equipment for its distribution [7].

\section{MATERIALS AND METHODS}

In this study, a model 1993 Renault 12 TSW vehicle was used in the experiments. The technical characteristics of the vehicle and the engine are presented in Table I.

TABLE I: THE TECHNICAL CHARACTERISTICS OF THE VEHICLE AND THE ENGINE USED IN THE STUDY

\begin{tabular}{lll}
\hline Engine Type & & 4 time \\
Engine Displacement & & 1397 \\
Number of Cylinders & & 4 \\
Cylinder bore & $\mathrm{mm}$ & 76 \\
Course length & $\mathrm{mm}$ & 77 \\
Maximum power & $\mathrm{BG}$ & $72(5200 \mathrm{~d} / \mathrm{d}$ 'da $)$ \\
Maximum Torque & $\mathrm{mkg}$ & $11(3000 \mathrm{~d} / \mathrm{d}$ 'da $)$ \\
Compression ratio & & 8.2 \\
Fuel system & & Carburator \\
Vehicle weight & $\mathrm{kg}$ & 950 \\
Wheelbase & $\mathrm{mm}$ & 2441 \\
\hline
\end{tabular}

The characteristics of the chassis dynamometer used in the experiments are given in Table II.

\begin{tabular}{lll}
\multicolumn{2}{c}{ TABLE II: THE PROPERTIES OF USED CHASSIS DYNAMOMETER } \\
\hline Brand & & $\mathrm{HPT}$ \\
Model & $\mathrm{m}$ & 6100 \\
Drum Diameter & 1.2 \\
Maximum Speed & $\mathrm{km} / \mathrm{h}$ & 200 \\
Maximum axle load & $\mathrm{kN}$ & 35 \\
Capacity & $\mathrm{kW}$ & 170 \\
\hline
\end{tabular}


The technical information on the exhaust emission device used in the experiments is given in Table III.

\begin{tabular}{|c|c|c|}
\hline \multicolumn{3}{|l|}{ Measurement Ranges } \\
\hline $\mathrm{CO}$ & $\%$ & $0-9.99$ \\
\hline $\mathrm{CO}_{2}$ & $\%$ & 0.19 .99 \\
\hline $\mathrm{HC}$ & ppm & $0-2500$ \\
\hline$\lambda$ & $\%$ & $0-1.99$ \\
\hline $\mathrm{O}_{2}$ & $\%$ & $0-20.8$ \\
\hline $\mathrm{NO}_{\mathrm{x}}$ & ppm & $0-2000$ \\
\hline Operating Temperature & ${ }^{\circ} \mathrm{C}$ & $5-40$ \\
\hline Temperature Retention & ${ }^{\circ} \mathrm{C}$ & $(-20)-(+60)$ \\
\hline Supply voltage & $\mathrm{V}$ & 12 \\
\hline
\end{tabular}

An electronic scale with a precision of $1 \mathrm{~g}$ was used to measure the fuel consumption of the vehicle. The technical characteristics of this device are given in Table IV. The characteristics of the 95 octane gasoline used as reference fuel in the tests are given in Table V.

\begin{tabular}{lll} 
TABLE IV: THE TECHNICAL SPECIFICATIONS OF ELECTONIC SCALES USED \\
\hline Brand & & CAS \\
Model & & SW1 \\
Precision & gr & 1 \\
Measuring Weight & $\mathrm{kg}$ & 5 \\
Power supply & & Battery or \\
& & adapter \\
\hline
\end{tabular}

TABLE V: THE CHARACTERISTICS OF THE 95 OCTANE ED GASOLINE USED AS REFERENCE FUEL IN THE TESTS

\begin{tabular}{|c|c|c|c|}
\hline Property & Unit & $\begin{array}{l}\text { Reference } \\
\text { Min. }\end{array}$ & $\begin{array}{l}\text { Limit } \\
\text { Max. }\end{array}$ \\
\hline Density & $\mathrm{kg} / \mathrm{m} 3$ & 720 & 775 \\
\hline Gom available. & $\mathrm{mg} / 100 \mathrm{ml}$ & & 5 \\
\hline Oxidation stability & dak. & 360 & - \\
\hline Boiling Point Final & $\mathrm{C}$ & - & 210 \\
\hline $\begin{array}{l}\text { The distillation Residue } \\
\text { to rate }\end{array}$ & $\%(\mathrm{v} / \mathrm{v})$ & - & 2 \\
\hline Evaporation (E70) & $\%(\mathrm{v} / \mathrm{v})$ & $\begin{array}{l}20.0 \text { (Yaz) } \\
22.0 \text { (Kış) }\end{array}$ & $\begin{array}{l}48.0 \text { (Yaz) } \\
50.0 \text { (Kış) }\end{array}$ \\
\hline Evaporation (E100) & $\%(\mathrm{v} / \mathrm{v})$ & 46.0 & 71.0 \\
\hline Evaporation (E150) & $\%(\mathrm{v} / \mathrm{v})$ & 75.0 & - \\
\hline Vapour Pressure & $\mathrm{kPa}$ & $\begin{array}{l}45.0(\mathrm{Yaz}) \\
60.0 \text { (Kış) }\end{array}$ & $\begin{array}{l}60.0 \text { (Yaz) } \\
90.0 \text { (Kış) }\end{array}$ \\
\hline Oxygen & $\%(\mathrm{~m} / \mathrm{m})$ & - & 2,7 \\
\hline Methanol & $\%(\mathrm{v} / \mathrm{v})$ & - & 3 \\
\hline Ethanol & $\%(\mathrm{v} / \mathrm{v})$ & - & 5 \\
\hline Iso-propyl alcohol & $\%(\mathrm{v} / \mathrm{v})$ & - & 10 \\
\hline Iso-butyl alcohol & $\%(\mathrm{v} / \mathrm{v})$ & - & 10 \\
\hline Tertiary-butyl Alcohol & $\%(\mathrm{v} / \mathrm{v})$ & - & 7 \\
\hline Ethers & $\%(\mathrm{v} / \mathrm{v})$ & - & 15 \\
\hline $\begin{array}{l}\text { Other Oxygen } \\
\text { Compounds }\end{array}$ & $\%(\mathrm{v} / \mathrm{v})$ & - & 10 \\
\hline Lead & $\mathrm{mg} / \mathrm{l}$ & - & 5 \\
\hline Sulfur & $\mathrm{mg} / \mathrm{kg}$ & - & 50 \\
\hline Benzene & $\%(\mathrm{v} / \mathrm{v})$ & - & 1 \\
\hline $\begin{array}{l}\text { Research Octane } \\
\text { Number }\end{array}$ & RON & 95 & 97,9 \\
\hline Motor octane number & MON & 85 & - \\
\hline
\end{tabular}

First, the vehicle was placed on the dynamometer and the connections were completed. Then the exhaust gas analysis device was connected to the vehicle. The fuel tank of the vehicle was removed and a separate fuel tank was attached to the vehicle and placed on the precision scale. The cooling fan was placed to the front of the vehicle in a manner that would not affect the precision scale. Gasoline-bioethanol blends containing $2 \%$ and $5 \%$ ethanol by volume were prepared by using bioethanol that was produced from sugar beet and gasoline.

\section{EXPERIMENT RESULTS AND DISCUSSION}

The amounts of $\mathrm{CO}$ emitted as the result of the combustion of E2 and E5 fuels compared to E0 reference fuel depending on the speed of the vehicle are given as percentages in Fig. 1. When the graphs were analyzed, with the increase of ethanol, a significant decrease was observed in the amount of $\mathrm{CO}$ emitted at all vehicle speeds. When the data regarding E2 and E5 fuels were compared, it was observed that E5 fuel showed lower CO values at low and average vehicle speeds. However, as the engine speed increased, a very small amount of increase was observed in $\mathrm{CO}$ emissions.

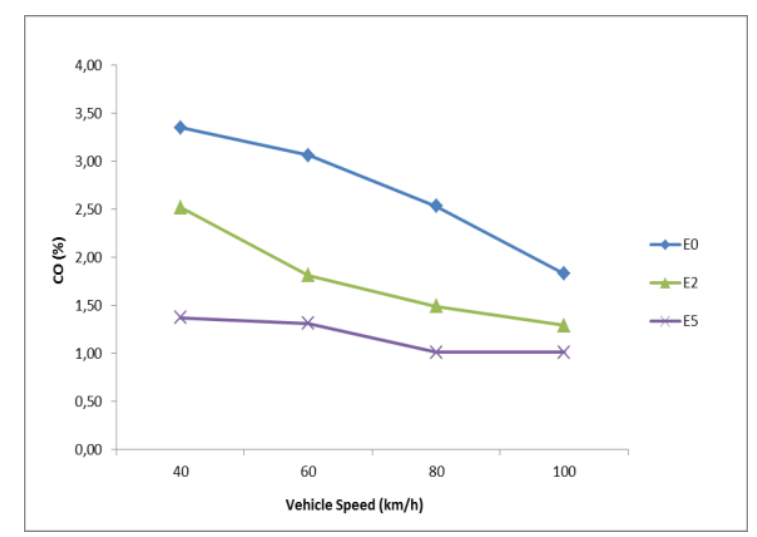

Fig. 1. The change in $\mathrm{CO}$ values with respect to vehicle speed.

The amounts of $\mathrm{CO}_{2}$ emitted as the result of the combustion of E2 and E5 fuels compared to E0 reference fuel depending on the speed of the vehicle are given as percentages in Fig. 2. When the graphs were analyzed, a significant decrease was observed in the amount of $\mathrm{CO}_{2}$ emitted at all vehicle speeds with the increase of the amount of ethanol. As the vehicle speed increased, the amounts of decrease observed in $\mathrm{CO}_{2}$ emitted also showed an increase.

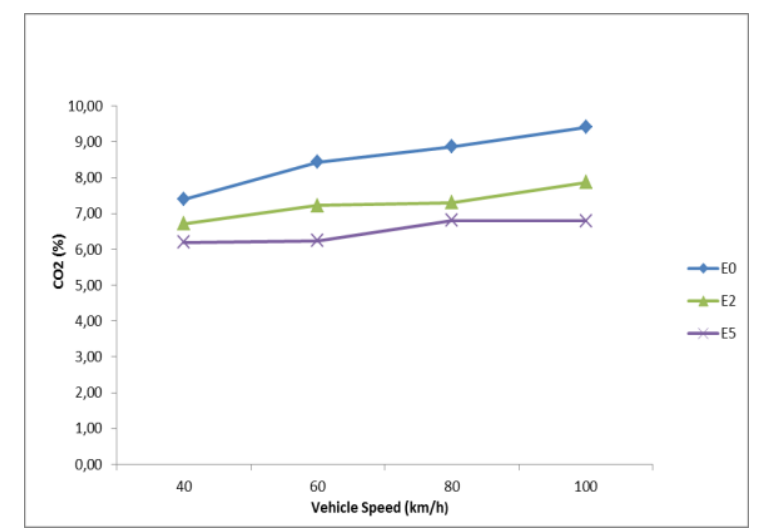

Fig. 2. The change in $\mathrm{CO}_{2}$ values with respect to vehicle speed.

The amount of $\mathrm{HC}$ emissions obtained as the result of the combustion of E0, E2 and E5 fuels depending on the speed of the vehicle are presented in ppm in Fig. 3. Although the HC values observed in the exhaust gases emitted through the 
combustion of E2 were similar at low speeds, an increase was observed at average speed. However, these values continued to decrease as the vehicle speed increased. The combustion of E5 fuel yielded lower HC emissions compared to both the reference fuel and the $\mathrm{E} 2$ fuel at all speeds.

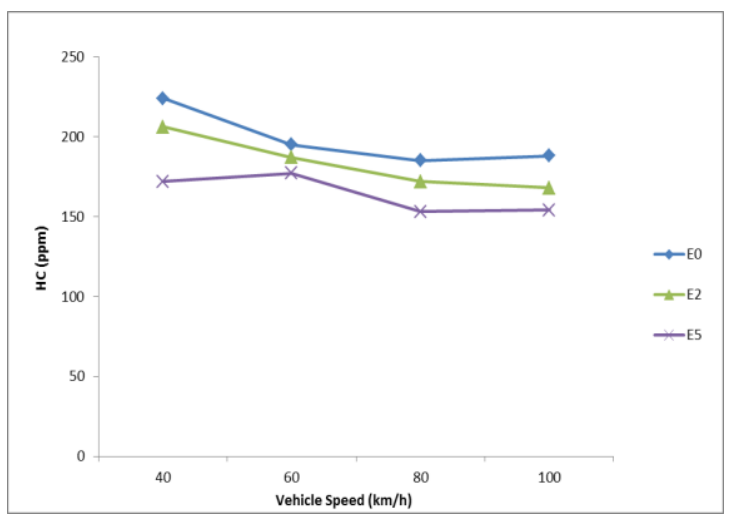

Fig. 3. The change in $\mathrm{HC}$ values with respect to vehicle speed.

The $\mathrm{O}_{2}$ values observed in the exhaust gases as the result of the combustion of E0, E2 and E5 fuels depending on the speed of the vehicle are presented in Fig. 4. As expected, the $\mathrm{O}_{2}$ emission values of bioethanol-blended fuels were found to be higher when compared to the reference fuel. Generally, with the increase of the amount of ethanol, the amount of $\mathrm{O}_{2}$ in the exhaust gases also increased. At speeds higher than 60 $\mathrm{km} / \mathrm{h}, \mathrm{O}_{2}$ values observed in the exhaust gases emitted through the combustion of E0 are lower compared to the $\mathrm{O}_{2}$ values observed in the exhaust gases emitted through the combustion of E2 and E5.

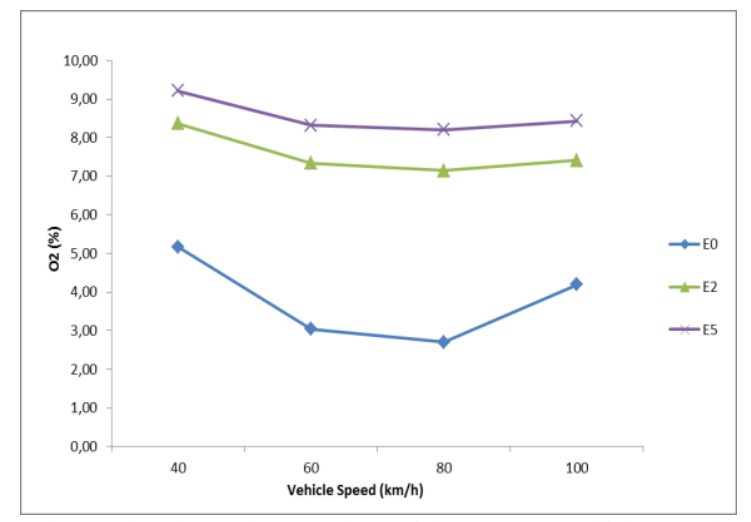

Fig. 4. The change in $\mathrm{O}_{2}$ values with respect to vehicle speed.

NOx emission values of E0, E2 and E5 type fuels depending on the vehicle speed are given in Fig. 5. Fuels with ethanol content showed higher values at low and average speeds when compared to the reference fuel, but both ethanol-blended fuels yielded lower results at high speed. When a threefold evaluation was conducted among the three types of fuels, the order of the fuels from high to low was in the sequence of E5-E2-E0 at low and average speeds. However, this sequence changed by reversing to the order of E0-E2-E5 at high speed.

The amount of percentage change in $\mathrm{CO}, \mathrm{CO}_{2}, \mathrm{HC}$, and $\mathrm{NO}_{\mathrm{x}}$ emissions that occurred as the result of the use of E2 and E5 fuels compared to ed gasoline (E0) when $60 \mathrm{~km} / \mathrm{h}$ was taken as the average vehicle speed are presented in Table VI below.

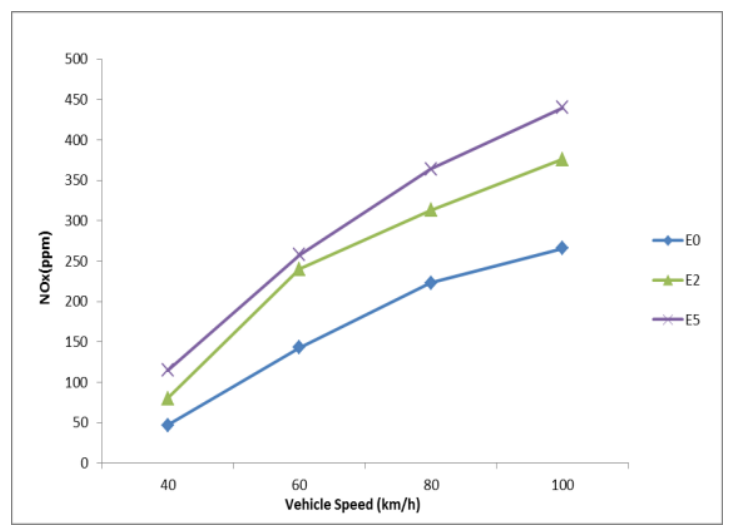

Fig. 5. The change in NOx values with respect to vehicle speed

TABLE VI: $60 \mathrm{KM} / \mathrm{H}$ IN THE PERCENTAGE OF EMISSIONS
\begin{tabular}{|c|l|c|c|}
\hline Emissions/Fuel & $\mathrm{E} 0$ & $\mathrm{E} 2$ & E 5 \\
\hline $\mathrm{CO}(\%)$ & 3,06 & $-40,85$ & $-57,19$ \\
\hline $\mathrm{CO}_{2}(\%)$ & 8,44 & $-14,46$ & $-26,07$ \\
\hline $\mathrm{HC}(\mathrm{ppm})$ & 195 & $+8,20$ & $-9,24$ \\
\hline $\mathrm{NO}_{\mathrm{x}}(\mathrm{ppm})$ & 143 & $+79,10$ & $+62,93$ \\
\hline
\end{tabular}

\section{CONCLUSION}

In this study, the effects of ethanol that was extracted from biomass on $\mathrm{CO}, \mathrm{CO}_{2}, \mathrm{HC}$ and $\mathrm{NO}_{\mathrm{x}}$ emissions were investigated. The physical and chemical properties of bioethanol render it a convenient alternative fuel for spark-ignition engines in vehicles. In the study, gasoline-bioethanol blends containing $2 \%$ and $5 \%$ ethanol by volume were used.

The CO emissions were found to be lower in both E2 and E5 blends when compared to ed gasoline. When the average speed of a vehicle was considered to be $60 \mathrm{~km} / \mathrm{h}$ in the city, a $40,85 \%$ decrease was observed with the use of E2 and a $57,19 \%$ decrease was observed with the use of E5 when compared to E0 fuel. As it can be seen in the graphs, this amount of decrease in $\mathrm{CO}$ emissions showed a rise as the amount of bioethanol in the blend and the vehicle speed increased. The reason for this decrease in $\mathrm{CO}$ emissions with the use of bioethanol blend was interpreted as indicating that bioethanol contains oxygen and for this reason the amount of oxygen in blended fuels is higher than that of in ed gasoline.

When $\mathrm{CO}_{2}$ emission values were examined, it was seen that the values were initially close to each other. However, with the increase of vehicle speed, $\mathrm{CO}_{2}$ emission value started to increase when ed gasoline was used. $\mathrm{CO}_{2}$ emission values showed a small amount of increase at first with the use of E2 blend. Afterwards, the values started to decrease dependent on increasing vehicle speed. A $14,46 \%$ decrease was observed with the use of E2 fuel and a 26,07\% decrease was observed with the use of E5 fuel at a speed of $60 \mathrm{~km} / \mathrm{h}$. It was seen that there was a decrease of approximately up to $35 \%$ compared to ed gasoline. Regarding the E5 blend, although the initial $\mathrm{CO}_{2}$ emission value was very close to the value obtained using E2, a small amount of increase was observed with the increase in vehicle speed. However, the values obtained by using the blended fuels are approximately $30 \%$ lower compared to ed gasoline.

Examining the $\mathrm{HC}$ emissions, it can be seen that a certain amount of decrease occurred with the use of ed gasoline depending on the vehicle speed. The results obtained by using 
the E2 blend initially show a value close to the ones obtained through ed gasoline use. However, $\mathrm{HC}$ emission level starts to fall with the increase in vehicle speed and gains a $15 \%$ lower value at higher speeds. At lower speeds, the $\mathrm{HC}$ emission values obtained from E5 blend were found to be approximately $30 \%$ lower when compared to ed gasoline. At high speeds, however, the HC emission values obtained through the combustion of E2 and E5 blends were similar but about $30 \%$ lower when compared to ed gasoline. The decrease observed in $\mathrm{HC}$ emission can be explained by the increase in vehicle speed together with the increase in engine speed; because, as the engine speed increases, the amount of heat that comes out as the result of the combustion of fuel in the cylinder increases and combustion improves.

When the $\mathrm{O}_{2}$ emission values in the exhaust gases were examined, the $\mathrm{O}_{2}$ emission values of both E2 and E5 blends were found to be higher when compared to ed gasoline. Particularly at high vehicle speeds, the $\mathrm{O}_{2}$ values measured in the exhaust gases of E2 and E5 blends were found to be approximately more than $100 \%$ higher compared to ed gasoline. The chemical formula of the ethanol fuel is $\mathrm{C}_{2} \mathrm{H}_{5} \mathrm{OH}$. As it can also be seen in the formula, ethanol fuel contains oxygen. The amount of oxygen that enters into the engine increases due to the oxygen that exists in the fuel. For this reason, an increase is observed in the amount of $\mathrm{O}_{2}$ in the exhaust gas.

NOx emission values of E2 and E5 blends at low speeds were observed to be generally higher compared to ed gasoline. NOx emission values obtained through using E2 decreased at rates exceeding $20 \%$ at low and high speeds. NOx emission values measured in the exhaust gases as the result of using E5 blend showed a decrease at high speeds. It is inevitable that the amount of NOx in the exhaust gas increases due to the increase in the amount of oxygen taken into the cylinder, because bioethanol fuel contains oxygen. At high vehicle speeds, NOx values obtained as the result of the use of ed gasoline were found to be $20-50 \%$ higher when compared to E2 and E5 blends.

In the study, it was seen that there was no necessity for a change or modification of the existing engine structure in order to use E2 and E5 blends.

\section{REFERENCES}

[1] T. Topgül, H. S. Yücesu, C. Çinar, and A. Koca, "The effects of ethanol-unleaded gasoline blends and ignition timing on engine performance and exhaust emissions," Renewable Energy, vol. 31, issue 15, pp. 2534-2542, 2006.

[2] S. Guven and O. Guneser, "Biyoetanol üretimi ve önemi," Gida Teknolojileri Elektronik Dergisi, vol. 1, pp. 91-96, 2007.

[3] Appendix Q. Production of ethanol from sugar beet. [Online]. Available: http://www.shu.ac.uk/rru/reports

[4] M. Koca, Y. Sekmen, T. Topgül, and H. S. Yücesu, "The effects of ethanol-unleaded gasoline blends on engine performance and exhaust emissions in a spark-ignition engine," Renewable Energy, vol. 34, pp. 2101-2106, 2009.

[5] L.-B. Wen, C.-Y. Xin, and S.-C. Yang, "The effect of adding dimethyl carbonate (DMC) and ethanol to unleaded gasoline on exhaust emission," Applied Energy, vol. 87, pp. 115-121, 2010.

[6] W.-D. Hsieha, R.-H. Chenb, T.-L. Wub, and T.-H. Lina, "Engine performance and pollutant emission of an SI engine using ethanol-gasoline blended fuels," Atmospheric Environment, vol. 36 , pp. 403-410, 2002.

[7] H. Kima and B. Choia, "Effect of ethanol-diesel blend fuels on emission and particle size distribution in a common-rail direct injection diesel engine with warm-up catalytic converter," Renewable Energy, vol. 33, pp. 2222-2228, 2008.

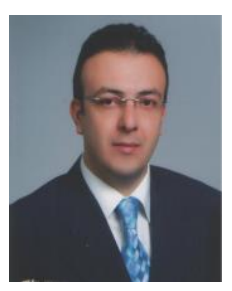

A. Engin Özçelik was born in Beyşehir, Konya. He graduated from Sakarya University, Faculty of Technical Education in 2001. Then he finished his $\mathrm{PhD}$ program in November 2011. He is a research assistant at Selcuk University now and studying with energy issue.

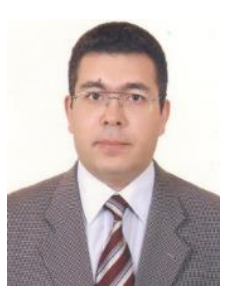

Hasan Aydoğan was born in Eskisehir. He graduated from Ankara Gazi University, Faculty of Technical Education in 1994. Then he received his $\mathrm{PhD}$ degree in November 2010. He is working as an assistant professor at the Selcuk University now and studying with energy issue.

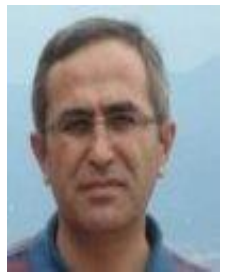

Mustafa Acaroğlu was born in Gokyurt, Turkey. He graduated from Konya Selcuk University, Faculty of Agricultural. He is working as a professor at the Selcuk University now. His research areas are energy and fuel issue. Prof. Dr. Mustafa Acaroglu had published four books. 